\title{
Thermo-economic modeling of an atmospheric SOFC/CHP cycle: an exergy based approach
}

\author{
Ghasem Arab $^{1}$, Hossein Ghadamian ${ }^{2, a}$ and Saeed Abbasi ${ }^{3}$ \\ 1 Department of Energy Engineering, College of Energy and Environment, Tehran Science and Research Branch, Islamic Azad \\ University, Tehran, Iran \\ 2 Department of Energy, Materials and Energy Research Center (MERC), P.O. Box 14155-4777, Tehran, Iran \\ 3 Department of Machine Design, Royal Institute of Technology (KTH), SE 10044 Stockholm, Sweden
}

Received 2 November 2013, Accepted 2 January 2014

\begin{abstract}
Sustainability is one of the challenging issues in electricity production systems. Recently, solid oxide fuel cell (SOFC) has been suggested for use in combined heat and power (CHP) systems. This application is introduced as a promising environmentally-friendly system according to the thermodynamic and electrochemical models. In this paper, an atmospheric SOFC/CHP cycle was analysed based on integrating exergy concepts, energy and mass balance equations. In this regard, a zero-dimensional energy and mass balance model was developed in engineering equation solver (EES) software. Two dimensionless parameters (the exergetic performance coefficient (EPC) for investigating the whole cycle, and exergetic efficiency for investigating the exergy efficiency of the main component of this cycle) were applied. Results show that efficiencies of the system have been increased substantially. The electrical efficiency, total efficiency and EPC of this cycle were $\sim 54 \%, \sim 79 \%$ and $\sim 58 \%$ respectively. Moreover, the $\mathrm{CO}_{2}$ emission is $19 \%$ lower than when compared with a conventional combined power cycle fed by natural gas. In addition, a dynamic economic evaluation was performed to extract the most sensitive parameters affecting the outputs: electricity sales price (ESP), equipment purchase cost and fuel cost. Furthermore, an electricity production cost of $\sim 125 \$ \mathrm{MW} \cdot \mathrm{h}^{-1}$ was attributed to our model, resulting in yet further cost reduction for widespread applications of this cycle.
\end{abstract}

Key words: SOFC / CHP / exergy efficiency / thermo-economic / EPC

\section{Introduction}

Power generation is essential and the current global trend shows increasing demand. Based on the proven advantages such as high electrical efficiency, high power density, low pollution and noise production the SOFC technology is suggested as a promising eco-friendly alternative in power generation systems [1]. SOFC can operate with various kinds of fuels such as natural gas, carbon monoxide, methanol, ethanol and hydrocarbon compounds, which facilitates a wide range of applications [2]. Due to the relatively high operational temperature $\left(800-1000{ }^{\circ} \mathrm{C}\right)$, this technology appears more appropriate for integration with CHP systems applications, thus developing distributed generation systems, increasing overall plant efficiency and leading to a clean cycle [3].

Farhad et al. [4] investigated the performance of a biogas fuelled SOFC/MCHP system thorough a numerical simulation. They achieved a parametric analysis of three

${ }^{a}$ Corresponding author: h.ghadamian@merc.ac.ir configurations including anode recirculation, steam reforming and partial oxidation. Their results confirmed that the net AC electrical efficiency attainable for these configurations was around $42.4 \%, 41.7 \%$ and $33.9 \%$ respectively. Staffell [5] conducted an economic feasibility study in domestic applications based on the use of SOFC technology in CHP systems, with positive results. Kuramochi [6] performed an economic feasibility study of SOFC/CHP cycles for market penetration by considering environmental constraints in the energy market. The results showed that $\mathrm{SOFC} / \mathrm{CHP}$ without $\mathrm{CO}_{2}$ capture requires a low $\mathrm{SOFC}$ total production cost of about $310 \$ \mathrm{~kW}^{-1}$ to compete with conventional GE/CHP. Meanwhile, SOFC/CHP with $\mathrm{CO}_{2}$ capture using an air separation unit (large scale type) can compete with $\mathrm{GE} / \mathrm{CHP}$ at higher stack production costs when the $\mathrm{CO}_{2}$ price is above $37 \$ \mathrm{tCO}_{2}^{-1}$.

Nanaeda et al. [7] studied the dynamic modelling of $\mathrm{SOFC} / \mathrm{CHP}$ cycles in various operational conditions and their connections to the national power grid. Analytical 


\section{Nomenclature}

\begin{tabular}{|c|c|c|c|}
\hline$V_{\text {act }}$ & Activation polarization & \multicolumn{2}{|c|}{ Greek symbols } \\
\hline$U_{\mathrm{a}}$ & Air utilization factor & $\eta$ & Efficiency \\
\hline$A$ & Area $\left(m^{2}\right)$ & $y_{i}$ & Mole fraction \\
\hline$A_{\text {act }}$ & Cell active area $\left(\mathrm{m}^{2}\right)$ & $\varepsilon$ & Recuperator effectiveness \\
\hline$i$ & Cell current density $\left(\right.$ A.m $\left.{ }^{-2}\right)$ & \multicolumn{2}{|c|}{ Abbreviation } \\
\hline$V$ & Cell voltage (V) & A.B & After Burner \\
\hline$V_{\text {con }}$ & Concentration polarization & CAPEX & Capital Expenditure \\
\hline$C$ & Cost $(\$)$ & $\mathrm{CHP}$ & Combined Heat and Power \\
\hline$P_{\mathrm{SOFC}}$ & DC SOFC power $(\mathrm{kW})$ & DHW & Domestic Hot Water \\
\hline$K p_{\mathrm{r}, \mathrm{s}}$ & Reforming, Shifting equilibrium constant & Eco & Economizer \\
\hline$\dot{E x}$ & Exergy $(\mathrm{kW})$ & EES & Engineering Equation Solver \\
\hline$F$ & Faraday constant (96 $485 \mathrm{As} \mathrm{mol}^{-1}$ ) & $\mathrm{EPC}$ & Exergetic Performance Coefficient \\
\hline$U_{f}$ & Fuel utilization factor & ESP & Electricity Sales Price \\
\hline$\dot{n}$ & $\mathrm{H}_{2}$ reacted moles $\left(\mathrm{mol} . \mathrm{s}^{-1}\right)$ & GE & Gas Engine \\
\hline$\dot{Q}$ & Heat $(\mathrm{kW})$ & HPR & Heat to Power Ratio \\
\hline$L H V$ & Lower heating value $\left(\mathrm{kJ} \cdot \mathrm{mol}^{-1}\right)$ & IR & Internal Reformer \\
\hline$\dot{m}$ & Mass flow rate (g.s $\left.{ }^{-1}\right)$ & MCHP & Micro CHP \\
\hline$\dot{n}_{i}$ & Molar flow rate $\left(\mathrm{mol}_{\mathrm{s}} \mathrm{s}^{-1}\right)$ & OPEX & Operational Expenditure \\
\hline$E_{\mathrm{re}}$ & Nernst voltage (V) & $\mathrm{SOFC}$ & Solid Oxide Fuel Cell \\
\hline$N_{\text {cell }}$ & Number of cells & IRR & Internal Rate of Return \\
\hline$V_{\text {ohm }}$ & Ohmic polarization & \multicolumn{2}{|c|}{ Subscripts and Superscripts } \\
\hline$D T_{\mathrm{p}}$ & Pinch point temperature difference $(\mathrm{K})$ & an & Anode \\
\hline$\dot{W}$ & Power $(\mathrm{kW})$ & aux & Auxiliary \\
\hline$V_{\mathrm{P} . \mathrm{R}}$ & Pre-reformer volume $\left(\mathrm{m}^{3}\right)$ & ca & Cathode \\
\hline$P$ & Pressure (bar) & $\mathrm{ch}$ & Chemical \\
\hline$n l$ & Project life time (yr) & inv & $\mathrm{DC} / \mathrm{AC}$ inverter \\
\hline$e x$ & Specific exergy & $\mathrm{D}$ & Destruction \\
\hline$h$ & Specific molar enthalpy $\left(\mathrm{kJ} . \mathrm{kmol}^{-1}\right)$ & Out & Outlet \\
\hline$s$ & Specific molar entropy (kJ.(kmol.K $\left.)^{-1}\right)$ & $\mathrm{ph}$ & Physical \\
\hline$S C R$ & Steam to carbon ratio & rec & Recuperator \\
\hline$T$ & Temperature (K) & 0 & Reference condition \\
\hline$R_{\mathrm{u}}$ & Universal gas constant (kJ.(kmol.K $\left.)^{-1}\right)$ & $t$ & Total \\
\hline
\end{tabular}

results indicated that with a $13.1 \%$ average increase in ESP, the system can provide the grid with a $50 \%$ operating range of dispatchable urban power at an overall thermal efficiency of $80 \%$.

It should be noted that the afore mentioned studies focused just on thermodynamic and/or thermo-economic analyses based on energy balance, and less attention has been paid to the concept of useful work (exergy) in those papers and in other studies [8-16].

In this paper, the exergetic analyses were carried out for all pieces of equipment after introducing two new parameters: the equipment exergetic efficiency and EPC. To meet this requirement, the SOFC/CHP cycle was modelled in the open source code of EES software, and equations for mass and energy balance, electrochemical and exergy were solved simultaneously. Our proposed model was then validated with the data reported in previous research. The final stage in our thermo-economic model was a dynamic economic study based on the dominant direct and indirect costs. A one-way sensitivity analysis was applied to determine the most influential parameter for decision making and facilitating widespread application of this system.

\section{Cycle description}

Figure 1 shows a schematic view of the SOFC module and CHP module in this study. Methane fuel enters the blower from stream 1 and mixes with anode recirculation depleted fuel before entering the pre-reformer and finally entering the SOFC's anode. As shown, air enters the cycle from stream 8 and after leaving the blower, is preheated in the recuperator, finally entering the SOFC's cathode. In the after burner, some of the fuel exiting from the anode burns with depleted air from the cathode (stream 12). After preheating the input air in the recuperator, the flue gases pass through the economizer 


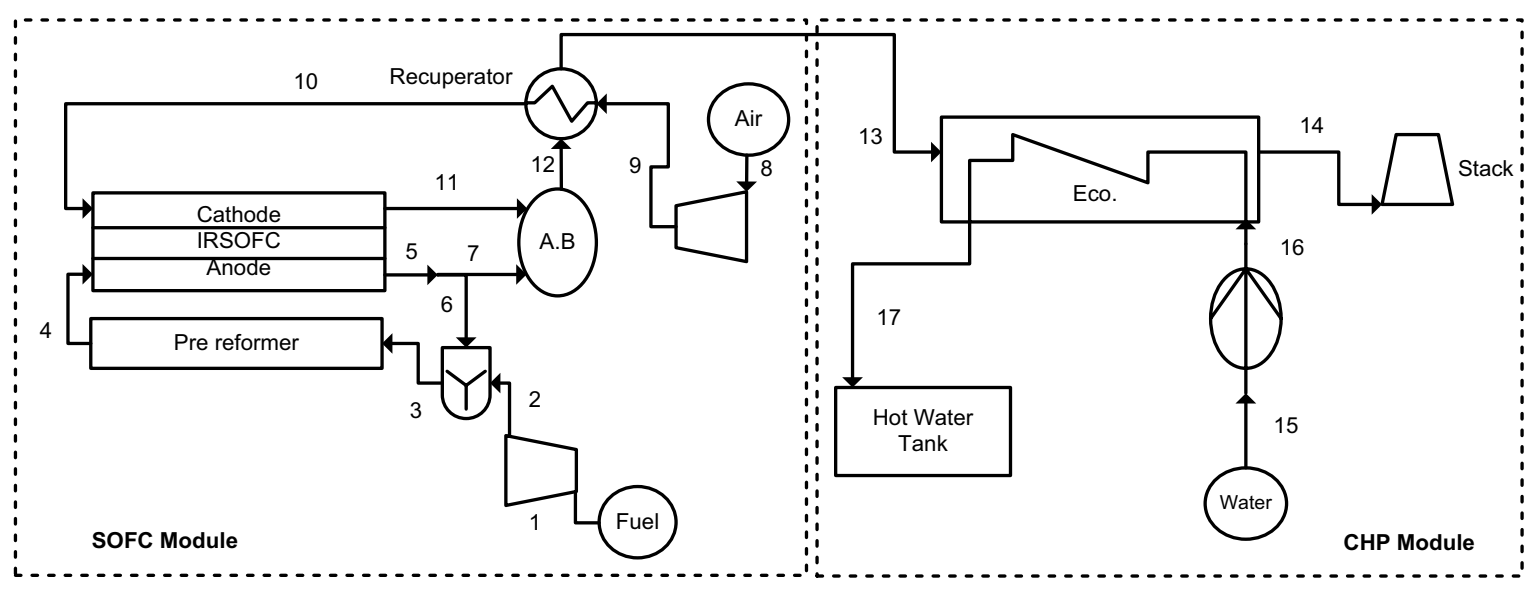

Fig. 1. A schematic view of a methane-fuelled SOFC/CHP system with internal reformer and anode off-gas recirculation.

(stream 13) with sufficient temperature to supply the energy for hot water applications such as space heating or domestic applications.

\section{Modeling methodology}

The principle concept of the SOFC module is converting the chemical energy of fuel directly into electrical energy. This objective is achieved through a series of electrochemical reactions [17]. The main application of the CHP module in power generation systems is producing hot water by using the excess heat of the after burner exhaust stream.

These two systems were integrated in our proposed model, which was developed based on the following assumptions:

1- System components are taken as a lumped control volume.

2- Equipment is issued in steady state conditions.

3- All chemical reactions reach equilibrium.

4- All gases are ideal gases.

To begin with, a zero-dimensional thermodynamic model of steady state flow was developed to simulate the system by using mass and energy balance equations. This computational model determined molar flow values $\left(\dot{n}_{i}\right)$, mole fractions $\left(y_{i}\right)$ and also physical properties such as enthalpy and entropy of all addressed streams shown in Figure 1. In order to keep continuity, output parameters from a piece of equipment were considered as input parameters to the next one. Table 1 shows all of the governing equations in this study.

\subsection{Exergy modeling}

In exergy modelling, the location and amount of exergy losses are determined in a target energy system. The system efficiency will increase by reducing energy losses, leading to an ideal state. The purpose of this analysis is to identify the location, type and amount of entropy during variations, and also to determine the effective factors of these irreversibilities. This procedure will shed more light on available effective alternatives to increase system efficiency.

The specific total exergy (ex) includes four components. When surface tension, magnetic and electrical effects are negligible, the specific total energy can be obtained from equation (3-a). Equation (3-b) can be derived for the physical exergy at the cycle if we assume the potential and kinetic exergies are negligible. The chemical exergy of an ideal mixture of $N$ ideal gases is obtained according to equation (3-c). The $e x_{k}^{\mathrm{CH}}$ is the standard molar chemical exergy for substance $k$, assuming the ambient temperature is $T_{0}$ and $y_{k}$ is mole fraction of the substance $k$ at temperature $T_{0}$ [18]. In each control volume, the exergy destruction rate is calculated according to equation (3-d). Afterward, the total exergy destruction in the cycle is provided by equation (3-e). For another point of view, exergy efficiency in each piece of equipment expresses the entropy generation and is calculated by using equation (3-f). The EPC is a concept as it presents a holistic evaluation of the exergetic patterns. Equation (3-g) was used to determine EPC.

\subsection{SOFC module modeling}

The SOFC module includes the fuel blower, mixer, pre-reformer, ejector, tubular SOFC stack and AC-DC inverter. All of the design parameter and technical specifications in this module are based on [19].

The methane is used as input fuel, entering the fuel blower (stream 1) where it is mixed with depleted recirculation fuel coming back from the anode side (stream 6) at the mixer. Output fuel from the anode includes more steam and extra heat energy for the fuel reforming process, so part of it is returned by an ejector and is added to the input fuel. The amount of returned fuel can be estimated with equation (4), according to the steam to carbon ratio, which is strongly related to the anode 
Table 1. List of equations in this model.

\begin{tabular}{|c|c|c|}
\hline $\begin{array}{l}\text { Description } \\
\text { (equipment) }\end{array}$ & Equation & No. \\
\hline Mass balance & $\sum \dot{m}_{\mathrm{in}}=\sum \dot{m}_{\mathrm{out}}$ & $(1)$ \\
\hline Energy balance & $\sum \dot{Q}_{\text {in }}+\sum \dot{W}_{\text {in }}+\sum \dot{n}_{\text {in }} h_{\text {in }}=\sum \dot{Q}_{\text {out }}+\sum \dot{W}_{\text {out }}+\sum \dot{n}_{\text {out }} h_{\text {out }}$ & $(2)$ \\
\hline Specific exergy & $e x=e x^{\mathrm{PH}}+e x^{\mathrm{ke}}+e x^{\mathrm{pe}}+e x^{\mathrm{ch}}$ & $(3-\mathrm{a})$ \\
\hline Physical exergy & $e x^{\mathrm{PH}}=\left(h-h_{0}\right)-T_{0}\left(s-s_{0}\right)$ & $(3-b)$ \\
\hline Chemical exergy & $e x^{\mathrm{ch}}=\sum y_{\mathrm{k}} e x_{\mathrm{k}}^{\mathrm{CH}}+R_{\mathrm{u}} T_{0} \sum y_{k} \ln y_{k}$ & $(3-c)$ \\
\hline Exergy destruction & $\dot{E} x_{\mathrm{D}}=\sum_{j} \dot{Q}_{j}\left(1-\frac{T_{0}}{T_{j}}\right)-\dot{W}+\sum_{i}\left(\dot{E} x_{i}\right)_{\mathrm{in}}-\sum_{i}\left(\dot{E} x_{i}\right)_{\mathrm{out}}$ & $(3-d)$ \\
\hline Total exergy destruction & $\dot{E}_{\mathrm{X}_{\mathrm{D}, \text { total }}}=\sum_{i} \dot{E}_{\mathrm{X}_{\mathrm{D}, i}}$ & $(3-e)$ \\
\hline $\begin{array}{l}\text { Exergetic efficiency, } \\
\text { equipment order } i\end{array}$ & $E E f_{i}=\left(1-\frac{\dot{E}_{\mathrm{X}_{\mathrm{D}, i}}}{E_{\mathrm{X}_{\mathrm{in}, i}}}\right) \times 100$ & $(3-f)$ \\
\hline EPC of cycle & $E P C=\left(1-\frac{\dot{E}_{\mathrm{X}_{\mathrm{D}, \text { total }}}}{E_{\mathrm{X}_{\mathrm{fuel}, \text { in }}}}\right) \times 100$ & $(3-g)$ \\
\hline $\begin{array}{l}\text { Steam to carbon ratio } \\
\text { (pre-reformer) }\end{array}$ & $S C R=\frac{\dot{n}_{3, \mathrm{H}_{2} \mathrm{O}}}{\dot{n}_{3, \mathrm{CH}_{4}}}$ & (4) \\
\hline Reforming process & $\mathrm{CH}_{4}+\mathrm{H}_{2} \mathrm{O} \rightarrow \mathrm{CO}+3 \mathrm{H}_{2}$ & $(5)$ \\
\hline $\begin{array}{l}\text { (Pre-reformer \& SOFC) } \\
\text { Shifting process } \\
\text { (Pre-reformer \& SOFC) }\end{array}$ & $\mathrm{CO}+\mathrm{H}_{2} \mathrm{O} \rightarrow \mathrm{CO}_{2}+\mathrm{H}_{2}$ & (6) \\
\hline Process equilibrium of reforming process & $K p_{\mathrm{r}}=\frac{p_{\mathrm{H}_{2}}^{3} p_{\mathrm{CO}}}{p_{\mathrm{CH}_{4}} p_{\mathrm{H}_{2} \mathrm{O}}}$ & (7) \\
\hline Process equilibrium of shifting process & $K p_{\mathrm{s}}=\frac{p_{\mathrm{H}_{2}} p_{\mathrm{CO}_{2}}}{p_{\mathrm{CO}} p_{\mathrm{H}_{2} \mathrm{O}}}$ & $(8)$ \\
\hline Electrochemical process (SOFC) & $\mathrm{H}_{2}+\frac{1}{2} \mathrm{O}_{2} \rightarrow \mathrm{H}_{2} \mathrm{O}$ & (9) \\
\hline Utilization factor (SOFC) & $\mathrm{U}_{\mathrm{f}}=\frac{\dot{n}}{4 \dot{n}_{1, \mathrm{CH}}}$ & $(10)$ \\
\hline Means of the recuperator effectiveness & $\varepsilon_{\mathrm{rec} 1}=\frac{T_{10}-T_{9}}{T_{12}-T_{9}}$ & $(11)$ \\
\hline Cell voltage (SOFC) & $V=E_{\mathrm{re}}-V_{\mathrm{act}}-V_{\mathrm{ohm}}-V_{\mathrm{con}}$ & $(12)$ \\
\hline SOFC power & $\mathrm{P}_{\mathrm{SOFC}}=\frac{N_{\text {cell }} \times V \times i \times \mathrm{A}_{\mathrm{act}}}{1000}$ & $(13)$ \\
\hline SOFC output power & $\dot{W}_{\mathrm{SOFC}}=\eta_{\mathrm{inv}} P_{\mathrm{SOFC}}$ & $(14)$ \\
\hline Minimum temperature difference & $T_{14}=T_{17}+D T_{\mathrm{p}}$ & $(15)$ \\
\hline Economizer energy balance & $\dot{n}_{13} h_{13}+\dot{n}_{16} h_{16}-\left(\dot{n}_{14} h_{14}+\dot{n}_{17} h_{17}\right)=0$ & $(16)$ \\
\hline Electrical efficiency & $\eta_{\mathrm{ele}}=\frac{\dot{W}_{\mathrm{net}}}{\dot{n}_{\mathrm{CH} 4} L H V}$ & $(17)$ \\
\hline Total efficiency & $\eta_{\mathrm{t}}=\frac{\dot{W}_{\mathrm{net}}+\dot{Q}_{\mathrm{CHP}}}{\dot{n}_{\mathrm{CH} 4} L H V}$ & $(18)$ \\
\hline
\end{tabular}


Table 2. System component purchase cost data summary.

\begin{tabular}{lll}
\hline Equipment & Cost model equation & No. \\
\hline SOFC [22] & $C_{\text {SOFC }}=A_{\text {act }} N_{\text {cell }}\left(2.96 . T_{\text {SOFC }}-1907\right)$ \\
Inverter [22] & $C_{\text {inv }}=10^{5} \times\left(\frac{\dot{W}_{\text {SOFC }}}{500}\right)^{0.7}$ \\
Blower (air \& fuel) [22] & $C_{\text {blower }}=91562\left(\frac{\dot{W}_{\text {blower }}}{445}\right)^{0.67}$ \\
Pre-reformer [23] & $C_{\text {P.R }}=130\left(\frac{A_{\mathrm{P} . \mathrm{R}}}{0.093}\right)^{0.78}+3240 V_{\mathrm{P} . \mathrm{R}}^{0.4}+21280.5 V_{\mathrm{P} . \mathrm{R}}$ \\
SOFC auxiliary equipment $[22]$ & $C_{\text {aux }}=0.1 \times C_{\mathrm{SOFC}}$ \\
HRSG [22] & $C_{\mathrm{HRSG}}=8600+670\left(A_{\mathrm{HRSG}}\right)^{0.83}$ \\
Recuperator [22] & $C_{\text {Recuperator }}=130\left(A_{\text {Recuperator }} / 0.093\right)^{0.78}$
\end{tabular}

recirculation process. For proper operation of the prereformer system, the steam to carbon ratio (identified a non dimensional ratio) is usually assumed between 2 and 3 as a constant [20].

Output fuel from the mixer (stream 3) enters the pre-reformer where reforming and shifting reactions occur as mentioned in equations (5) and (6). In relation to this, part of the inlet methane and carbon monoxide are converted to hydrogen. As a statement and to ensure completion for reactions, the equilibrium temperature is considered equal to the outlet temperature from the prereformer $\left(T_{4}\right)[19]$. The amounts of reformed methane and shifted carbon monoxide are determined using the equilibrium constant equations (7) and (8). The required heat of this section is provided by the SOFC fuel cell stack. The equilibrium constants and thermal functions $K p_{r}$ and $K p_{s}$ are deterministic and temperature dependent [20].

Gases leaving the pre-reformer enter the internal reformer SOFC stack and the reactions of equations (5), (6) and (9) occur simultaneously. It is theoretically assumed that the whole input methane to the SOFC is reformed and off-gases are methane free. The molar rate of the consuming hydrogen is determined by the utilization factor presented in equation (10).

There is a complexity to converge the equation with iterative procedures in modelling, which is the overall cycle dependency related to unknown initial composition of anode off-gas.

The recuperator effectiveness $\left(\varepsilon_{\text {rec }}\right)$ is calculated by equation (11).

The SOFC module voltage is calculated according to equation (12). In this equation the $E_{\mathrm{re}}$ is determined by the nernst equation, where as the $V_{\text {act }}$, is obtained using the butler-volmer equation. $V_{\mathrm{ohm}}$ is evaluated by using an equation concerning thermal resistance in the anode, cathode, electrodes and inter-connector. In addition, $V_{\text {con }}$ is determined based on voltage drops according to an approach in [21]. Finally, inserted cell voltage relating to equation (13) and (14) will clear the exact amount of power (DC or AC type) of the SOFC module.

\subsection{CHP module modeling}

The CHP module is an important part of the system affecting the characteristics of the overall cycle. The recuperator's exhaust gas flow has enough energy to supply the required energy for hot water demand. This module includes an economizer, circulation pump and hot water reservoir. In CHP systems, water is pumped to the required head and then, in the economizer, is heated to the desirable temperature $\left(90{ }^{\circ} \mathrm{C}\right)$ by the hot gas flow. $D T_{p}$ is the minimum pinch point temperature difference which is utilized by equation (15). Then, the flow rate of hot water production can be determined based on energy balance equation (16).

\subsection{Economic modeling}

Economic modelling takes place using a time-bounded dynamic model and equipment cost functions. The main considered equipments, are the SOFC stack and auxiliaries, DC/AC inverter, blowers, recuperator, prereformer and CHP module. The equipment purchase cost functions are presented in Table 2 (Eqs. (19) to (25)). The total summation of the direct costs (e.g. landscaping, installation, instrumentation, piping etc.) and indirect costs (constructions, engineering and etc.) along with investment costs are considered as CAPEX. The other terms, like energy and production costs, are considered as $O P E X$.

For further explanation, the incomes should be considered in two categories, namely ESP and saved energy in the CHP module.

\subsection{Initial input parameter}

Table 3 shows the initial input parameters in the proposed model. 
Table 3. The initial input parameters of this SOFC/CHP system.

\begin{tabular}{|c|c|c|c|}
\hline Parameter & Value & Parameter & Value \\
\hline Reference condition & & SOFC module & \\
\hline Reference temperature $(\mathrm{K})$ & 298.15 & Air utilization factor & 0.20 \\
\hline Reference pressure (bar) & 1.013 & Fuel utilization factor & 0.85 \\
\hline CHP module & & SCR & 3 \\
\hline Minimum temperature difference $(\mathrm{K})$ & 20 & Average current density $\left(\right.$ A.m $\left.{ }^{-2}\right)$ & 3200 \\
\hline Economizer pressure loss (\%) & 5 & SOFC pressure loss (\%) & 2 \\
\hline DHW temperature $(\mathrm{K})$ & 363.15 & Number of cells & 1152 \\
\hline COST model & & Cell active area $\left(\mathrm{m}^{2}\right)$ & 0.0834 \\
\hline Interest rate $(\%)$ & 12 & DC/AC inverter efficiency (\%) & 96 \\
\hline Fuel price $\left(\$\right.$ kg.methane $\left.{ }^{-1}\right)$ & 0.2585 & Air \& fuel blowers' efficiency (\%) & 85 \\
\hline Annually operation time (h.r) & 8760 & Recuperator pressure loss (\%) & 2 \\
\hline Life cycle time $(y r)$ & 10 & Recuperator effectiveness (\%) & 84 \\
\hline Electricity sale price $\left(\$ M W \cdot h^{-1}\right)$ & 117.84 & & \\
\hline Boiler efficiency (\%) & 0.85 & & \\
\hline
\end{tabular}

\section{Results and discussion}

\subsection{Modeling process and results}

The modelling results at different points of the cycle are presented in Table 4 . It should be noted that the rendered values in Table 4 are concluded based on the input parameters of Table 3. Other key features of the cycle and economic calculations are presented in Table 5.

According to these results, the electrical and overall efficiencies of this cycle reach $54.77 \%$ and $78.97 \%$ respectively, a range on par with the aforementioned studies $[1,9,11,12,15,17,23]$. The results also confirm the relatively high contribution of the SOFC stack and auxiliaries cost to the total investment. Consequently, any successful attempt to moderate those costs could lead to the widespread application of this system. In the current model, the electricity production cost is equal to $125.5 \$ \mathrm{MW} . \mathrm{h}^{-1}$, which is $6 \%$ higher than normal electricity production cost $117.84 \$ \mathrm{MW} \cdot \mathrm{h}^{-1}$ (Key World Energy Statistics, 2012).

According to Table 4, the rate of $\mathrm{CO}_{2}$ production in this system is $20.68 \mathrm{~g} . \mathrm{s}^{-1}$, resulting in the discharge of $52.16 \mathrm{tCO}_{2} \mathrm{yr}^{-1}$ to the atmosphere. Thus the specific $\mathrm{CO}_{2}$ production of this system is 360.50 g.kW.h ${ }^{-1}$, compared with the conventional gas fuelled combined power plants (large scale CHP systems) that generate 446 g.kW.h ${ }^{-1}$ $\mathrm{CO}_{2}$ [24], the present cycle show a reduction of $19.17 \%$ in $\mathrm{CO}_{2}$ emissions. This leads to a conflict of interests between the sustainability and environmental aspects, and the excess cost of produced electricity in comparison with conventional power systems [25].
In order to promote the analysis focused on exergy terms, this research carries out two non-dimensional variables (named equipment exergetic efficiencies and cycle EPC), leading to the SOFC/CHP modelling of exergetic results and details presented in Table 6 . The findings show that due to their high temperature loss, the recuperator and economizer have the most exergy destruction, highlighting the need for better cycle designs to degrade the temperature differences with in technical limitations. In other words, use of a low efficiency recuperator seriously decreases the electrical and overall efficiencies; thus, whilst use of an efficient recuperator and cleaning of the active heating area is recommended based on the presented model. The next reduction priorities related to exergy destructions are attributed to SOFC, due to the electrochemical reactions and after burner, due to the combustion process. As presented in Table 6, the total exergy destruction is $164.8 \mathrm{~kW}$, which is proportionately large considering that we produce a net output power of $206.5 \mathrm{~kW}$. Further studies based on power and efficiencies within exergy considerations to find better bounds of variations for mentioned terms seem necessary. To this end, the next step is parametric studies.

\subsection{Parametric study}

Generally, the input parameters are associated with uncertainties in real conditions. The electric power generation systems are not exceptional and input parameters can change over time due to unexpected reasons. 
Table 4. Characteristics of SOFC/CHP system at each stream for nominal condition.

\begin{tabular}{cccccccccccc}
\hline Streams & $T(\mathrm{~K})$ & $P($ bar $)$ & $\dot{m}\left(\mathrm{~g} \cdot \mathrm{s}^{-1}\right)$ & $\dot{E} x(\mathrm{~kW})$ & \multicolumn{9}{c}{ Molar fraction $(\%)$} \\
& & & & & $\mathrm{CH}_{4}$ & $\mathrm{CO}$ & $\mathrm{CO}_{2}$ & $\mathrm{H}_{2}$ & $\mathrm{H}_{2} \mathrm{O}$ & $\mathrm{N}_{2}$ & $\mathrm{O}_{2}$ \\
\hline 1 & 298.15 & 1.01 & 7.52 & 393.2 & 100.00 & - & - & - & - & - & - \\
2 & 298.15 & 1.32 & 7.52 & 393.5 & 100.00 & - & - & - & - & - & - \\
3 & 1065.72 & 1.29 & 68.79 & 597.6 & 15.26 & 6.22 & 22.02 & 10.73 & 45.77 & - & - \\
4 & 850.00 & 1.29 & 68.79 & 617.3 & 4.84 & 12.86 & 18.87 & 33.29 & 30.14 & - & - \\
5 & 1242.49 & 1.26 & 94.35 & 325.4 & - & 7.34 & 25.99 & 12.66 & 54.01 & - & - \\
6 & 1242.49 & 1.26 & 61.27 & 211.3 & - & 7.34 & 25.99 & 12.66 & 54.01 & - & - \\
7 & 1242.49 & 1.26 & 33.09 & 114.1 & - & 7.34 & 25.99 & 12.66 & 54.01 & - & - \\
8 & 298.15 & 1.01 & 548.65 & 2.4 & - & - & - & - & - & 79.00 & 21.00 \\
9 & 298.15 & 1.32 & 548.65 & 14.8 & - & - & - & - & - & 79.00 & 21.00 \\
10 & 1173.00 & 1.29 & 548.65 & 297.4 & - & - & - & - & - & 79.00 & 21.00 \\
11 & 1242.49 & 1.26 & 523.08 & 316.0 & - & - & - & - & - & 82.46 & 17.54 \\
12 & 1341.66 & 1.24 & 556.17 & 403.6 & - & - & 2.41 & - & 4.82 & 77.10 & 15.67 \\
13 & 537.71 & 1.21 & 556.17 & 54.6 & - & - & 2.41 & - & 4.82 & 77.10 & 15.67 \\
14 & 383.15 & 1.17 & 556.17 & 21.0 & - & - & 2.41 & - & 4.82 & 77.10 & 15.67 \\
15 & 288.00 & 1.01 & 290.66 & 189.3 & - & - & - & - & 100.00 & - & - \\
16 & 288.20 & 1.08 & 290.66 & 189.3 & - & - & - & - & 100.00 & - & - \\
17 & 363.15 & 1.03 & 290.66 & 196.6 & - & - & - & - & 100.00 & - \\
\hline
\end{tabular}

Table 5. Technical and cost characteristic results of SOFC/CHP system modelling.

\begin{tabular}{|c|c|c|c|}
\hline \multicolumn{2}{|l|}{ Technical data } & \multicolumn{2}{|l|}{ Cost data } \\
\hline SOFC DC power $(\mathrm{kW})$ & 231.6 & CAPEX (\$) & 555613 \\
\hline SOFC AC power $(\mathrm{kW})$ & 222.4 & $\underline{\text { Direct cost }}$ & 457995 \\
\hline Economizer duty (kW) & 91.27 & Equipment cost $(\$)$ & 327139 \\
\hline Air blower power $(\mathrm{kW})$ & 15.24 & $\mathrm{SOFC}$ cost $(\$)$ & 170130 \\
\hline Fuel blower power $(\mathrm{kW})$ & 0.37 & $\mathrm{DC} / \mathrm{AC}$ inverter cost $(\$)$ & 56712 \\
\hline Net output power $(\mathrm{kW})$ & 206.5 & Pre-reformer cost $(\$)$ & 55400 \\
\hline Electrical efficiency (\%) & 54.77 & SOFC auxiliary cost $(\$)$ & 17013 \\
\hline Total efficiency (\%) & 78.97 & Economizer cost $(\$)$ & 11601 \\
\hline \multirow{2}{*}{ EPC of cycle (\%) } & \multirow{2}{*}{58.08} & Air blower cost $(\$)$ & 9546 \\
\hline & & Recuperator cost $(\$)$ & 5937 \\
\hline Voltage (V) & 0.75 & Fuel blower cost $(\$)$ & 800 \\
\hline HPR & 0.44 & $\underline{\text { Indirect cost }}$ & 97618 \\
\hline \multirow[t]{5}{*}{ Annual electricity production (GWh) } & 1.81 & OPEX (\$) & 128739 \\
\hline & & Total annual cost $(\$)$ & 227074 \\
\hline & & $\operatorname{IRR}(\%)$ & 12.88 \\
\hline & & Electricity production cost $\left(\$ M W \cdot h^{-1}\right)$ & 125.5 \\
\hline & & Specific power cost $\left(\$ \mathrm{~W}^{-1}\right)$ & 2.69 \\
\hline
\end{tabular}

In this regard we achieved a series of on-way sensitivity analysis for all factors. The result shows that $U_{f}$ is the most influential on the performance efficiency of this system. Figures $2 \mathrm{a}$ and $2 \mathrm{~b}$ show the results.

Figure 2a shows the effect of small changes of $U_{f}$ on economic power, SOFC power, Heat to Power Ratio $(H P R)$ and total exergy destruction. According to these results an increase in $U_{f}$ causes an increase in SOFC power, an exergetic performance coefficient. On the other hand, it leads to a decrease in $H P R$, economic power, total exergy destruction, total efficiency and cell voltage.

Actually, an increase in $U_{f}$ is attributable to an increase in SOFC fuel consumption which increases the SOFC power, the energetic performance coefficient and electrical efficiency. But it increases the irreversibility in the system (i.e. cell voltage drop). However, an increase 
(a)

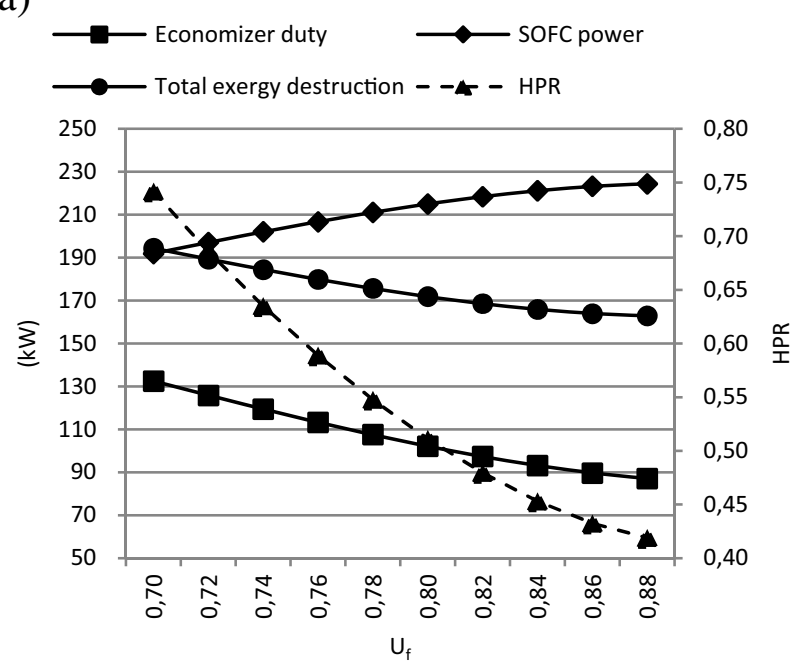

(b)
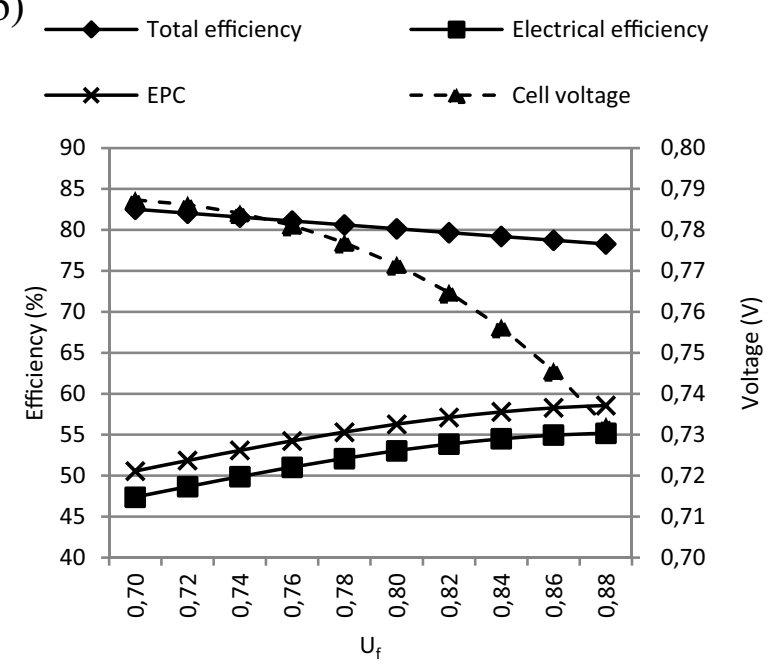

Fig. 2. Effect of fuel utilization factor on characteristics of SOFC/CHP system; (a) system powers and HPR; (b) efficiencies, exergetic performance coefficient and cell voltage.

(a)
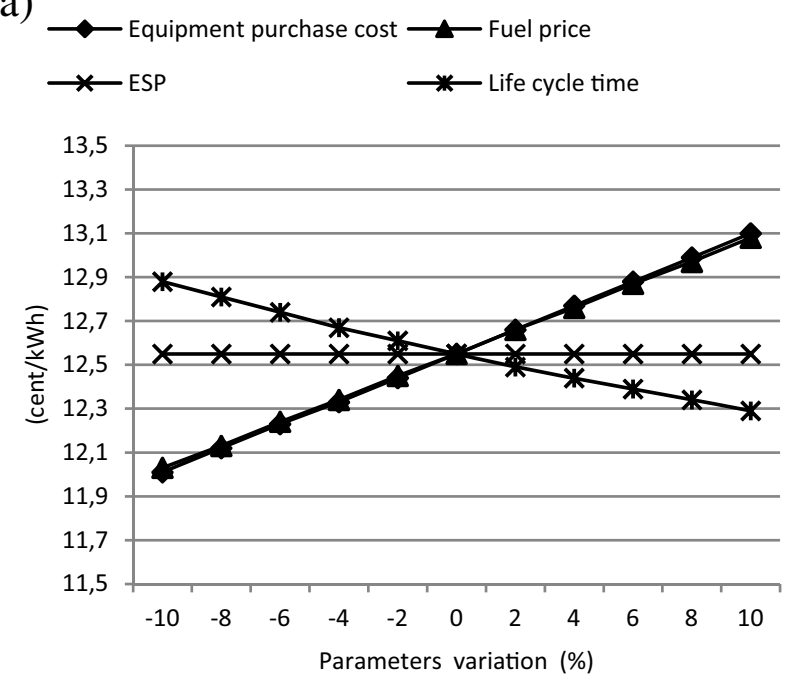

(b)
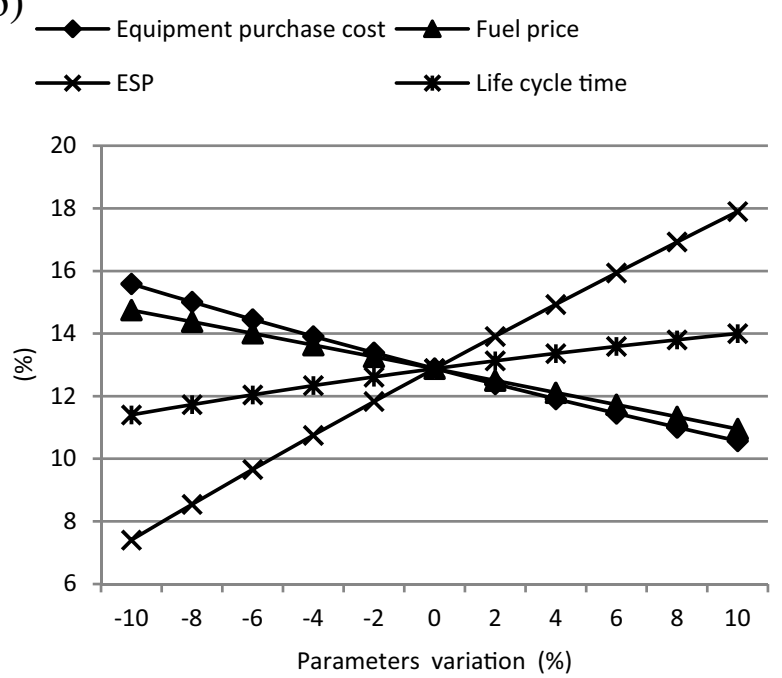

Fig. 3. Sensitivity analysis of economic characteristics of SOFC/CHP system; (a) electricity production cost; (b) IRR.

Table 6. Exergy destructions and exergetic efficiency results of SOFC/CHP system modelling.

\begin{tabular}{lcc}
\hline Equipment & $\begin{array}{c}\text { Exergy destructions } \\
(\mathrm{kW})\end{array}$ & $\begin{array}{c}\text { Exergetic efficiency } \\
(\%)\end{array}$ \\
\hline Recuperator & 66.4 & 84.13 \\
Economizer & 26.27 & 89.23 \\
After burner & 22.64 & 94.74 \\
Exhaust exergy & 21.02 & 0.00 \\
SOFC & 15.95 & 98.26 \\
Mixer & 7.21 & 98.81 \\
Air blower & 2.86 & 83.81 \\
Pre-reformer & 2.15 & 99.64 \\
Total & 164.8 & - \\
\hline
\end{tabular}

in SOFC fuel consumption leads to a shortage of SOFC fuel in the afterburner and a decline in the afterburner and economizer outlets temperature.
These results also suggest an optimum utilization value for $U_{f}$, when $U_{f}=0.84$, the maximum overall performance is achievable.

We also conducted a limited investigation on the effects of equipment purchase cost, fuel price, ESP and life cycle time over the following economical output characteristics:

- Total production cost as the main contributor in ESP.

- IRR as the main motivator for investors.

In this respect, we assumed $10 \%$ margin variation for the initial input values for equipment purchase cost, fuel price, ESP and life cycles time. Figure 3 shows the results. According to the ESP is the most influential factor in economic considerations. We can also prioritize the effect of equipment purchase cost, fuel price and life cycle time. 
Any other combination of the mentioned scenarios could be investigated in further studies.

\section{Conclusion}

The proposed exergy based thermo-economic modelling confirms the benefits of using of SOFC technology in CHP applications, as it provides:

1. High electrical and total efficiencies (electrical efficiency of $54.77 \%$, and total efficiency of $78.97 \%$ ).

2. An environmentally-friendly cycle with low $\mathrm{CO}_{2}$ emission compared with conventional combined power cycle fed by natural gas $\left(19.17 \%\right.$ reduction in $\mathrm{CO}_{2}$ emission).

3. Appropriate $H P R$ value, equal to 0.44, and high EPC, equal to 58.08 .

In addition, the following scenarios have a positive effect on the widespread applications of the proposed system:

a) increasing global ESP to $122.67 \$ \mathrm{MW} \cdot \mathrm{h}^{-1}$;

b) decreasing $8 \%$ in equipment purchase costs;

c) decreasing fuel prices to $0.2031 \$ \mathrm{~kg}$. methane $^{-1}$.

\section{References}

[1] S.C. Singhal, Advances in solid oxide fuel cell technology, Solid State Ion. 135 (2000) 305-313

[2] P. Chinda, S. Chanchaona, P. Brault, W. Wechsatol, A planar anode-supported Solid Oxide Fuel Cell model with internal reforming of natural gas, Eur. Phys. J. Appl. Phys. 54 (2011) 23405

[3] J. Pirkandi, M. Ghasemi, M.H. Hamedi, R. Mohammadi, Electrochemical and thermodynamic modeling of a CHP system using tubular solid oxide fuel cell (SOFC/CHP), J. Clean. Prod. 29-30 (2012) 151-162

[4] S. Farhad, F. Hamdullahpur, Y. Yoo, Performance evaluation of different configurations of bio SOFC micro/CHP systems for residential applications, Int. J. Hydrogen Energy 35 (2010) 3758-3768

[5] I. Staffell, R. Green, K. Kendall, Cost targets for domestic fuel cell CHP, J. Power Sources 181 (2008) 339-349

[6] T. Kuramochi, H. Wu, A. Ramírez, A. Faaij, W. Turkenburg, Techno-economic prospects for $\mathrm{CO}_{2}$ capture from a solid oxide fuel cell-combined heat and power plant, preliminary results, Energy Procedia 1 (2009) 3843-3850

[7] K. Nanaeda, F. Mueller, J. Brouwer, S. Samuelsen, Dynamic modeling and evaluation of solid oxide fuel cell heat and power system operating strategies, J. Power Sources 195 (2010) 3176-3185

[8] Y. Haseli, I. Dincer, G.F. Naterer, Thermodynamic modeling of a gas turbine cycle combined with a solid oxide fuel cell, Int. J. Hydrogen Energy 33 (2008) 5811-5822 http://iea.org/publications/freepublications/ publication/name, 31287, en.html, 28 Nov 2012
[9] X. Zhanga, S.H. Chan, G. Li, H.K. Ho, J. Li, Z. Feng, A review of integration strategies for solid oxide fuel cells, J. Power Sources 195 (2010) 685-702

[10] F. Calise, M. Dentice, L. Vanoli, M.R. Spakovsky, Full load synthesis/design optimization of a hybrid SOFC/GT power plant, Energy 32 (2007) 446-458

[11] E. Fontell, T. Kivisaari, N. Christiansen, J.B. Hansen, J. Palsson, Conceptual study of a $250 \mathrm{~kW}$ planar SOFC system for CHP application, J. Power Sources 131 (2004) 49-56

[12] M. Calì, M.G.L. Santarelli, P. Leone, Design of experiments for fitting regression models on the tubular SOFC/CHP100kWe: Screening test, response surface analysis and optimization, Int. J. Hydrogen Energy 32 (2007) 343-358

[13] R. Bove, S. Ubertini, Modeling solid oxide fuel cell operation: Approaches, techniques and results, J. Power Sources 159 (2006) 543-559

[14] V.M. Janardhanan, O. Deutschmann, Modeling of solid oxide fuel cell, Z. Phys. Chem. 221 (2007) 443-478

[15] S. Campanari, Thermodynamic model and parametric analysis of a tubular SOFC module, J. Power Sources 92 (2001) 26-34

[16] M. Dokiya, SOFC system and technology, Solid State Ionics 152-153 (2002) 383-392

[17] S.H. Chan, C.F. Low, O.L. Ding, Energy and Exergy analysis of simple solid oxide fuel cell power systems, J. Power Sources 103 (2002) 188-200

[18] T.J. Kutas, The exergy method of thermal plant analysis, Florida, Krieger Publishing Company, 1995

[19] A.V. Akkayaa, B. Sahinb, H.H. Erdema, An analysis of SOFC/GT/CHP system based on exergetic performance criteria, Int. J. Hydrogen Energy 33 (2008) 2566-2577

[20] P.G. Bavarsad, Energy and exergy analysis of internal reforming solid oxide fuel cell-gas turbine hybrid system, Int. J. Hydrogen Energy 32 (2007) 4591-4599

[21] S. Motahar, A.A. Alemrajabi, Exergy based performance analysis of a solid oxide fuel cell and steam injected gas turbine hybrid power system, Int. J. Hydrogen Energy 34 (2009) 2396-2407

[22] D.F. Cheddie, Thermo-economic optimization of an indirectly coupled solid oxide fuel cell/gas turbine hybrid power plant, Int. J. Hydrogen Energy 36 (2011) $1702-1709$

[23] A. Arsalis, Thermo-economic modeling and parametric study of hybrid SOFC-gas turbine-steam turbine power plants ranging from 1.5 to 10MWe, J. Power Sources 181 (2008) 313-326

[24] D. White, Reduction in Carbon Dioxide emissions: Estimating the potential contribution from wind Power, Renewable Energy Foundation, (2004) http://www.ref . org.uk/Files/david.white.wind.co2.saving.12.04. pdf, 19Dec2012

[25] A. Azhdari, H. Ghadamian, A. Ataei, C.K. Yoo, A new approach for optimization of combined heat and power generation in edible oil plants, J. Appl. Sci. 9 (2009) $3813-3820$ 